\title{
Embryonal Antigens in Maize Caryopses: The Temporal Order of Antigen Accumulation during Embryogenesis
}

\author{
E.E. Khavkin, S.I. Misharin, V.N. Ivanov \\ Siberian Institute of Plant Physiology and Biochemistry, Siberian Branch, \\ USSR Academy of Sciences, P.O. Box 1243, Irkutsk, USSR 664033 \\ K.N. Danovich \\ Department of Physiology, Irkutsk State University, Irkutsk, USSR 664003
}

\begin{abstract}
The sequential appearance of a specific group of embryonal antigens (EA), presumably globulins, was demonstrated in developing maize (Zea mays L.) caryopses using a double immunodiffusion test with absorption of common antigens. Cross immunoelectrophoresis was employed to follow the differential pattern of EA accumulation in the growing scutellum and embryonic axis. The transient nature of two predominant EA seems to indicate their role as specific protein reserves of embryonal tissues. Another presumably organ-specific EA was maintained in callus obtained from a 28-day-old culture of scutellum isolated from the mature non-germinated caryopsis.
\end{abstract}

Key words: Antigen accumulation - Embryogenesis - Globulins - Proteins - Seed proteins - Zea.

\section{Introduction}

The results of numerous investigations in animal embryology have confirmed the dogma of molecular biology that relates cell and tissue development to sequential gene repression and derepression (Markert and Ursprung, 1971). Immunological methods visualizing developmental changes in protein patterns have played an important role in these studies (for review see Vyasov, 1973). Much less data are available concerning selective gene expression and its timing in higher plants. Changes in antigen spectra seem to accompany the growth and differentiation of plant cells in vitro (Boutenko and Volodarsky, 1968) and in vivo (Wright, 1963; Daussant et al., 1969; Millerd et al., 1971; Misharin et al., 1974). However, most

Abbreviations: $\mathrm{DAP}=$ day(s) after pollination; $\mathrm{EA}=$ embryonal antigen(s) of these changes appear to be of a quantitative nature (Kawashima et al., 1967; Ivanov et al., 1974) and therefore do not unambiguously prove the synthesis of new proteins.

The well-known storage proteins of seeds, e.g., the globulins in legumes and prolamins in cereals (Osborne, 1924), are especially attractive materials for developmental studies since their synthesis represents an expression of a few genes during a relatively short time period and a massive translation of products of these genes (Bonner, 1965; Millerd et al., 1971). Various immunochemical procedures were applied to investigate the accumulation of reserve globulins in the growing pea and bean cotyledons (Bonner, 1965; Kloz et al., 1966; Millerd et al., 1971) and the deposition of prolamin in the developing wheat caryopsis (Pavlov et al., 1975). However, there is no reliable information concerning the formation of the tissueand organ-specific protein patterns in developing cereal embryos.

We have recently compared the antigen spectra of maize root and scutellum (Misharin et al., 1974) and found a characteristic group of antigens. They are abundant in the scutellum but can also be found in other parts of non-germinated caryopses. Most of these antigens disappear at the very onset of germination, and may therefore be tentatively defined as embryonal antigens. This paper describes the time course of EA accumulation in developing maize caryopses. A preliminary report including some of these data was published elsewhere (Misharin et al., 1975).

\section{Material and Methods}

Plant Material

Commercial batches of maize (Zea mays L.) seeds (caryopses), hybrid Bukovinsky 3 (cv. Gloria Janetski $\times$ Inbred A344), were ob- 
tained from the Krasnodar region. The seeds were surface-sterilized with $1 \%$ chloramine for $5 \mathrm{~min}$, rinsed thoroughfully with tap water, soaked in water for $2 \mathrm{~h}$ at $35-40^{\circ}$, and germinated in the dark on moist filter paper at $27^{\circ} \mathrm{C}$. When 3 days old, the seedlings were transferred to a glasshouse and grown under $10.5 \mathrm{~h}$ of natural light daily; later, when 1 month old, the plants were transferred into a field plot under a plastic film cover. In 1974, ears were hand-pollinated at the end of July, and 60 days later the kernels were fully mature. In 1975, plants were grown in sand culture, pollinated in June, and harvested in August:

Samples of silks, unfertilized and fertilized ovaries, and developing caryopses were collected for analysis at the desired intervals designated in terms of days after poilination (DAP). The caryopsis was divided into three parts: 1 . the embryonic axis; 2 . the scutellum; and 3. the rest of it, referred to below as the endosperm.

\section{Histological Procedure}

All samples were fixed in Carnoy mixture. Paraffin sections were stained either with Procion dyes (Ivanov and Lytinskaya, 1967), or by the Schiff-periodate reagent (Jensen, 1962).

\section{Extraction of Proteins}

Precooled or frozen samples were blended with 1 or 2 volumes $(\mathrm{w} / \mathrm{v})$ of ice-cold $0.1 \mathrm{M}$ Tris- $\mathrm{HCl}$ buffer, $\mathrm{pH} 8.2$, containing $10 \mathrm{mM}$ 2-mercaptoethanol. The homogenates were centrifuged for $25 \mathrm{~min}$ at $17,000 \times g$, and cell-free extracts were used for antigen spectra analysis or immunization. In the latter case low-molecular-weight substances were eliminated by gel-filtration through Sephadex G25 , and the protein solutions were freeze-dried. When the protein concentrations were insufficient for immunochemical procedures dry Sephadex was added, and the concentrated protein solution was separated either by centrifugation or by suction with a syringe. Protein content was measured with the Folin reagent (Lowry et al., 1951) after triplicate reprecipitation with trichloroacetic acid from alkaline solutions to remove traces of phenolic substances, Tris and mercaptoethanol. Bovine serum albumin was used to prepare the standard curve.

\section{Immunochemical Procedures}

Production of Polyvalent Antisera. Three groups of rabbits (two or three animals per group) were injected subcutaneously with $15 \mathrm{mg}$ of a protein preparation mixed with complete Freund's adjuvant, penicillin and streptomycin $\left(10^{5}\right.$ units each) per rabbit. Proteins were extracted from: 1 . the scutella of mature, non-germinated caryopses (to facilitate isolation of the scutella, the caryopses were imbibed for $2 \mathrm{~h}$ at $\left.6-8^{\circ}\right) ; 2$. the meristematic and 3 . the mature cells of roots of 3-day-old seedlings. Injections $(25-35 \mathrm{mg}$ protein in $2 \mathrm{ml}$ of physiological saline with incomplete Freund's adjuvant) were repeated twice at 14-day intervals; then the rabbits were reimmunized with $30-35 \mathrm{mg}$ protein without adjuvant in 1month intervals. The animals were bled from the ear vein, and the serum fraction was separated and assayed for qualitative differences in individual rabbit responses and titer using the routine Ouchterlony immunodiffusion test (Kabat and Mayer, 1964). Normal sera samples were pooled, and their $\gamma$-globulin content was enriched 5-6-fold by ammonium sulphate fractionation according to Kendall (Kabat and Mayer, 1964). Antisera suspensions in 33\% ammonium sulphate were stored in a refrigerator. When necessary, aliquots were centrifuged and the dissolved sera purified by gelfiltration.
Double Immunodiffusion. Our modification of the widely used "square" test (Abelev, 1960) employed the absorption of common antigens in the course of their diffusion through the barrier formed with heterologous antiserum (Misharin et al., 1974). The procedure was carried out on $75 \mathrm{~mm} \times 25 \mathrm{~mm}$ microscopic slides covered with $1 \%$ Difco agar in buffered ( $\mathrm{pH} 7)$ saline, containing 1:10,000 merthiolate, during 4 days at $6-8^{\circ} \mathrm{C}$. The gels were washed free of non-precipitated proteins by $3-4$ times change of saline, dried, and stained with amido black in usual manner. This technique is illustrated by Fig. 1A: scutellum antigens common with the root precipitate along the line $c-c^{\prime}$, while scutellum-specific antigens pass through the absorbing barrier and form the specific precipitin lines $s-s^{\prime}$ parallel to the barrier axis. Two kinds of control experiments were performed to check the efficiency of this procedure. No "specific" precipitin lines were found if the absorbing barrier was made of homologous antiserum (Fig. 1B). Only traces of common precipitin lines were produced if scutellar extract had been absorbed in a tube with root antiserum and the precipitate had been discarded before the immunodiffusion test (Fig. 1C).

The above technique has been further modified in our laboratory. "Squares" were combined in fours to compare specific precipitin lines belonging to several tissue samples by superposition (Fig. 1D).

The modified double-immunodiffusion test is a sensitive qualitative method for early detection of "new" antigens. However, the technique does not discriminate between qualitative changes in protein patterns and a substantial but merely quantitative in-

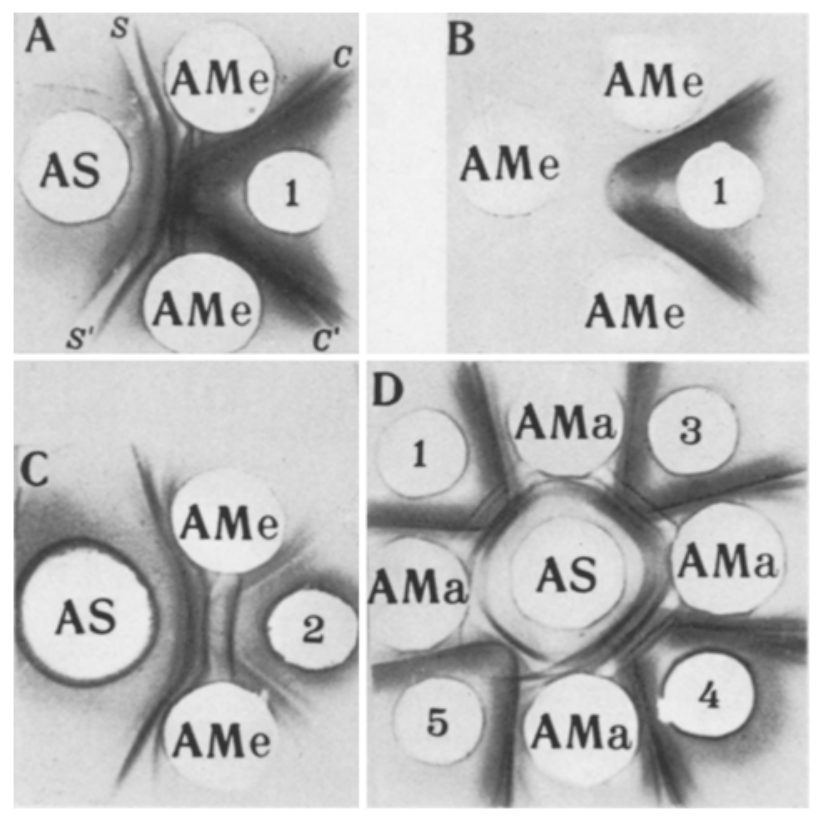

Fig. 1A-D. Demonstration of embryonal antigens (EA) by the double immunodiffusion test with absorption of common antigens. A EA in the scutellum; B test for the completeness of absorption during immunodiffusion in agar; $\mathbf{C}$ absorption of common antigens before the immunodiffusion test; $\mathbf{D}$ identification of the $\mathrm{EA}$ in various tissue samples. Antisera: AS, to proteins of the scutellum from the mature non-germinated caryopsis; $\mathrm{AMe}$, to proteins of the meristem in the seedling root; AMa, to proteins of the mature cells in the seedling root. Protein samples from non-germinated caryopses: (1) scutellum; (2) same after absorption with AMe; (3) root; (4) coleoptile; (5) endosperm; $c-c^{\prime}$ : common antigens; $s-s^{\prime}$ : specific antigens (EA) 


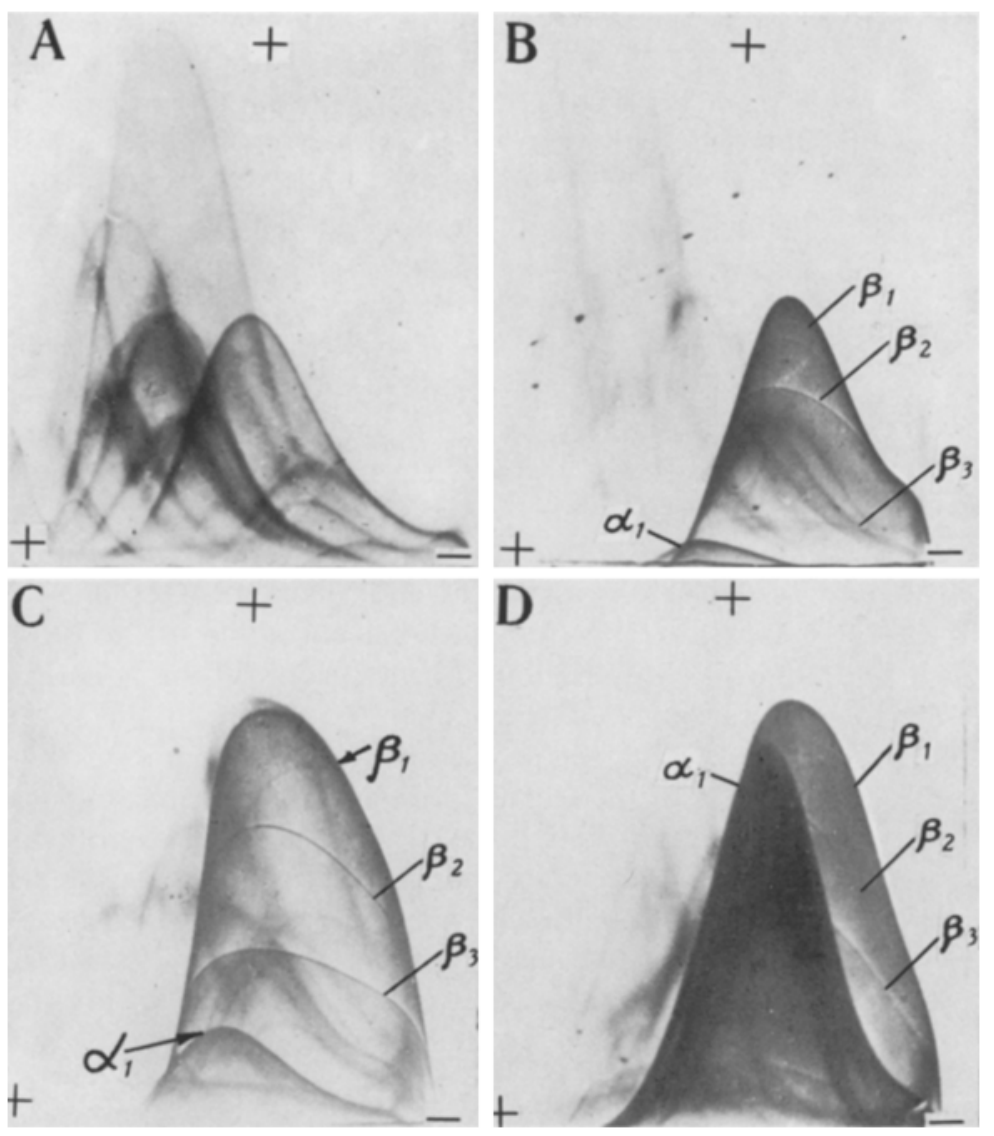

Fig. 2A-D. Demonstration of the EA by cross immunoelectrophoresis. A ovary, 2nd DAP; B embryonic axis, 32nd DAP; C scutellum, 38th DAP; D scutellum, mature non-germinated caryopsis. The agarose gel contained AS. $\alpha_{2}$ - and $\alpha_{3}$-EA precipitin lines in $\mathbf{C}$ and $\mathbf{D}$ were too faint to be reproduced crease in several antigens; for such a discrimination, cross immunoelectrophoresis is the method of choice.

Cross Immunoelectrophoresis. The two-dimensional (cross) immunoelectrophoretic procedure was generally applied as described by Laurell (1965) and Clarke and Freeman (1968). One-dimensional separation of proteins was carried out by the routine technique on glass microscope slides covered with $1 \%$ agarose gel in barbital buffer, pH 8.6, ionic strength 0.05 . Two wells were cut $15 \mathrm{~mm}$ from the short edge and $5 \mathrm{~mm}$ from the long edge of the slide. Each of two wells on every slide contained $0.03 \mathrm{ml}$ of protein solution (about $5-7 \mathrm{mg} / \mathrm{ml}$ ). The run was for $1.5 \mathrm{~h}$ at a potential gradient of $8 \mathrm{~V} \mathrm{~cm}^{-1}$. After the first run each gel was cut longitudinally into two 5 -mm-wide strips. They were transferred to a $9 \times 12$ $\mathrm{cm}$ glass plate, and the remaining area of the latter was filled with $30 \mathrm{ml}$ of agarose-antiserum solution ( $28 \mathrm{ml} 1 \%$ agarose in barbital buffer, $\mathrm{pH} 8.6$, plus $2 \mathrm{ml}$ of antiserum). The current in the second direction (at a right angle to the initial run) was 4 $\mathrm{V} \mathrm{cm}-1$ for $20 \mathrm{~h}$. All procedures were carried out in a coldroom. After separation gels were washed in buffered saline, dried, and stained with Coumassie brilliant blue R-250 according to the usual protocol.

The areas under the precipitin loops (Fig. 2) were measured with a planimeter. These areas are proportional to the protein concentrations, provided the antiserum concentration in the agarose layer is constant (Clarke and Freeman, 1968). Semiquantitative comparison of samples was made by simultaneous running of two samples, one of which was an external standard (e.g., from the scutellum of the non-germinated caryopsis), on the same glass plate. Concentrations of antigens were calculated relative to the standard for each antigen. Thus, provided the antigen properties of proteins did not change significantly (compare Crumpton, 1974) during embryogenesis, the development of antigen spectra could be investigated.

\section{Results}

\section{The Embryonic Antigens}

When the antigen patterns in the scutella of mature, non-germinated caryopses were compared to those in seedling roots, several EA were apparent in the scutella and absent in root cells. Five to six specific EA were detected in the double diffusion test (see Fig. $1 \mathrm{~A}$ and $\mathrm{C}$ ). Six EA were found after cross-electrophoretic separation (Fig. 2). The data obtained by the two methods are not completely comparable as some antigens can migrate towards the cathode during electrophoresis. The six antigens separated by electrophoresis could be subdivided into two groups (Fig. 2): the more mobile $\alpha$-EA and the less mobile $\beta$-EA. The $\alpha_{1}$-EA and $\beta_{1}$-EA predominated in the scutellum of the mature caryopsis, while the $\alpha_{2}-, \alpha_{3}^{-}, \beta_{2^{-}}$and $\beta_{3^{-}}$EA formed fainter and smaller precipitin loops. 


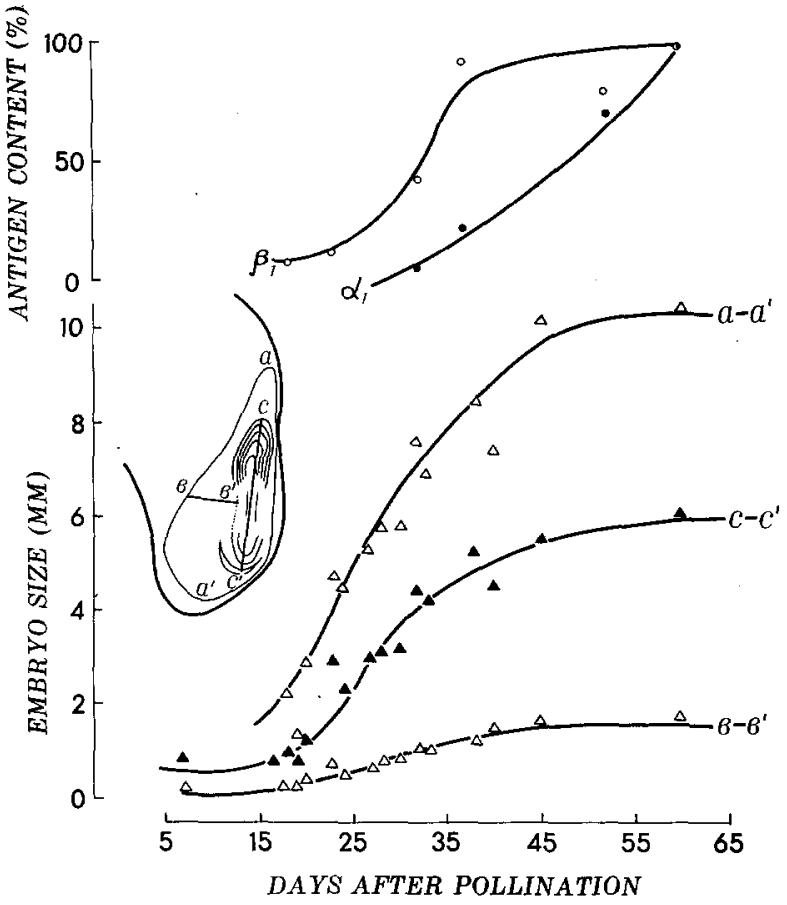

Fig. 3. Time course of $\beta_{1}$ - and $\alpha_{1}$-EA accumulation in the scutellum of the developing embryo. $a-a^{\prime}$ : the scutellum length along the absorbing epithelial layer; $b-b^{\prime}:$ the scutellum thickness; $c-c^{\prime}$ : the length of the embryonic axis

These EA were chosen as markers, and changes in the EA complement were further investigated in the developing caryopses.

\section{EA Changes during Caryopsis Development}

The time course of embryogenesis in maize under the conditions of our experiments in 1974 and 1975 did not differ significantly from that described earlier by Randolph (1936) and Modilevsky (1958). The crucial time points in the ontogeny of the embryo were:
1. change in the shape of the proembryo caused by the appearance of the plumule-root axis (between 8 and 12 DAP), 2. subsequent rapid development of leaf primordia, the root, and procambial strands (up to $18 \mathrm{DAP}$ ), and 3. differentiation of the epithelium, the mass of parenchyma cells, the conductive tissues and the epidermal layer in the scutellum (see also Kiesselbach and Walker, 1952). The number of leaf primordia increased to 5-6 at the time of physiological maturity (about 45 DAP), while most of the root cells by that time had become differentiated. The pattern of embryo growth is shown in Figure 3 . The size of the embryo axis rapidly increased between 18-20 and 38 DAP, the scutellum expanded first by both cell division and enlargement (up to 24-25 DAP), then by cell enlargement alone (up to $38-45$ DAP). At the end of the latter interval the coleorhiza became fully differentiated.

The EA seemed to be absent from the growing tissues of the female flowers of maize before pollination (Fig. 4); this was true both for dividing ovary cells and the rapidly elongating cells of the silks (stigmata). These tissues manifested the typical electrophoretic pattern consisting of 18-20 antigens characteristic, with quantitative fluctuations, of any growing cells in various organs of maize seedlings (Ivanov et al., 1974).

No EA could be found in the growing proembryo during the first 10 days of caryopsis development. On the 11th DAP, when organ differentiation in the embryo became visible, the first EA could be demonstrated by the double diffusion test (Fig. 5). Two EA were present on the 18th DAP, four on the 23rd DAP and on the 38th DAP, when the scutellum had reached more than $2 / 3$ of its final size, the EA pattern in the scutellum was completed.

Using cross-electrophoresis, we could detect $\beta_{1}$ EA by the 18 th DAP. Further sequential development of the $\beta$ - and $\alpha$-EA and their differential accumulation 


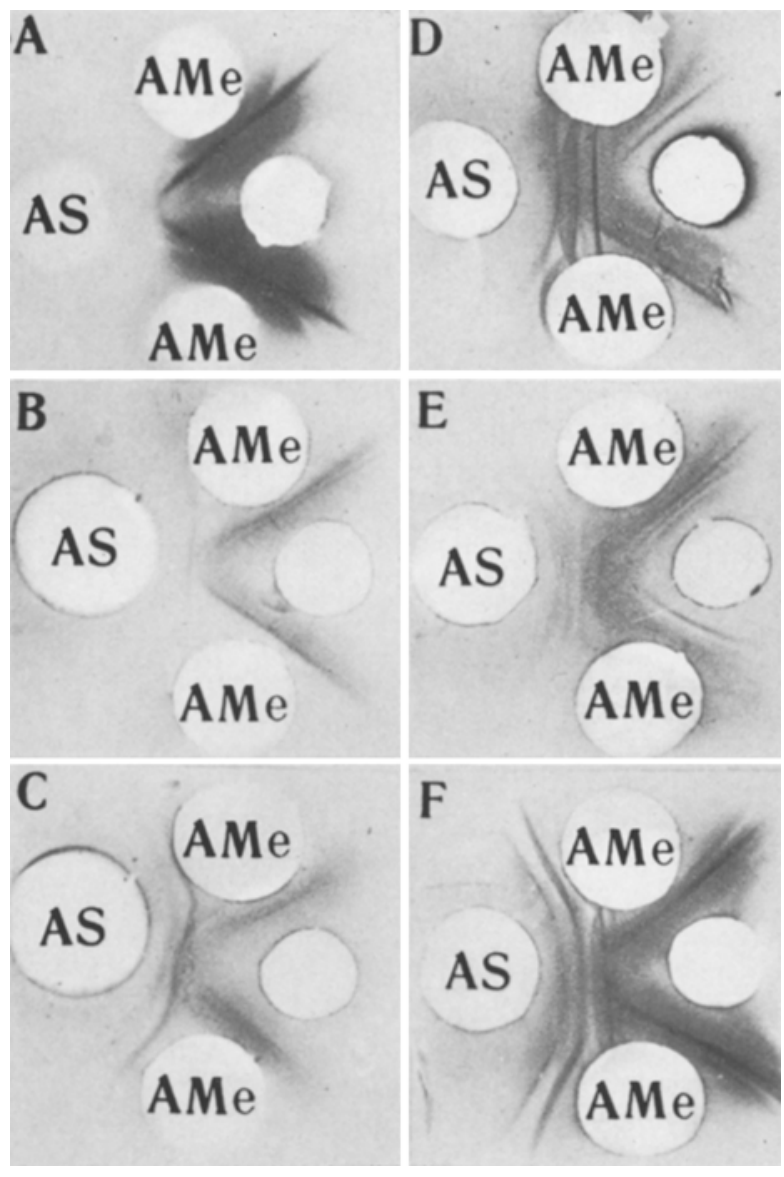

Fig. $5 \mathrm{~A}-$ F. Development of the EA pattern during embryogenesis. A ovary, 2nd DAP; B ovary, 11th DAP; C embryo, 18th DAP; D embryo, 23rd DAP; $\mathbf{E}$ scutellum, 38th DAP $; \mathbf{F}$ scutellum, mature non-germinated caryopsis

in the scutellum is shown in Figures 2, 3 and 6. When the axis was separated from the scutellum for analysis (beginning with the 32nd DAP), several EA, including the most prominent $\beta_{1}$ - and $\alpha_{1}$-EA, were found in the plumule-root tissue (Figs. 2 and 6).

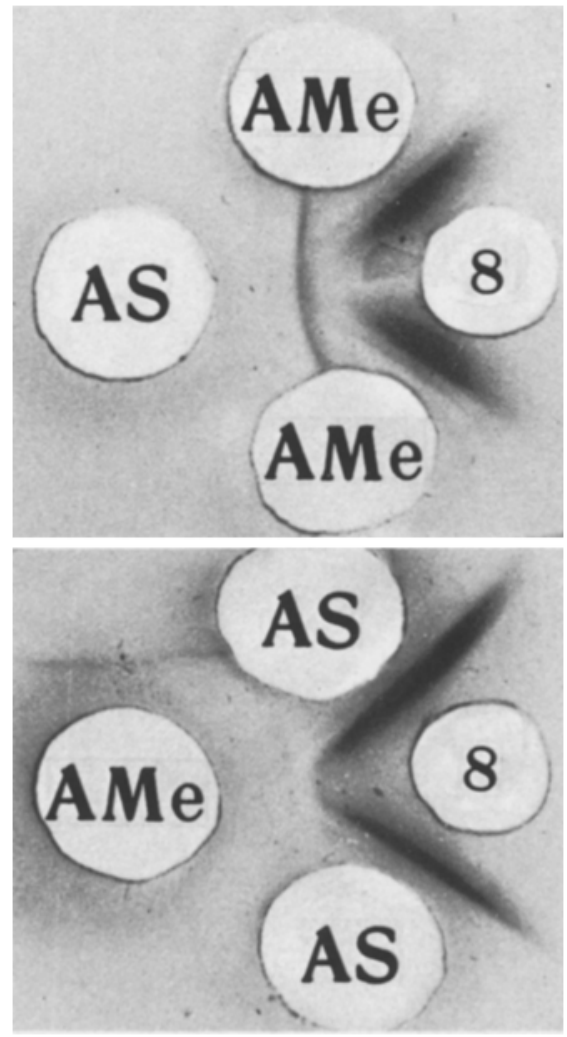

Fig. 7. The EA in callus obtained by culture of the scutellum of a mature, non-germinated maize caryopsis. (8) callus tissue, other as in Figure 1

In this way several EA absent from the root of 3-day-old seedlings appeared in the embryonic axis and accumulated considerably during its development. At least four of the EA, including the most abundant ones of them $-\beta_{1}$ and $\alpha_{1}-$ are by no

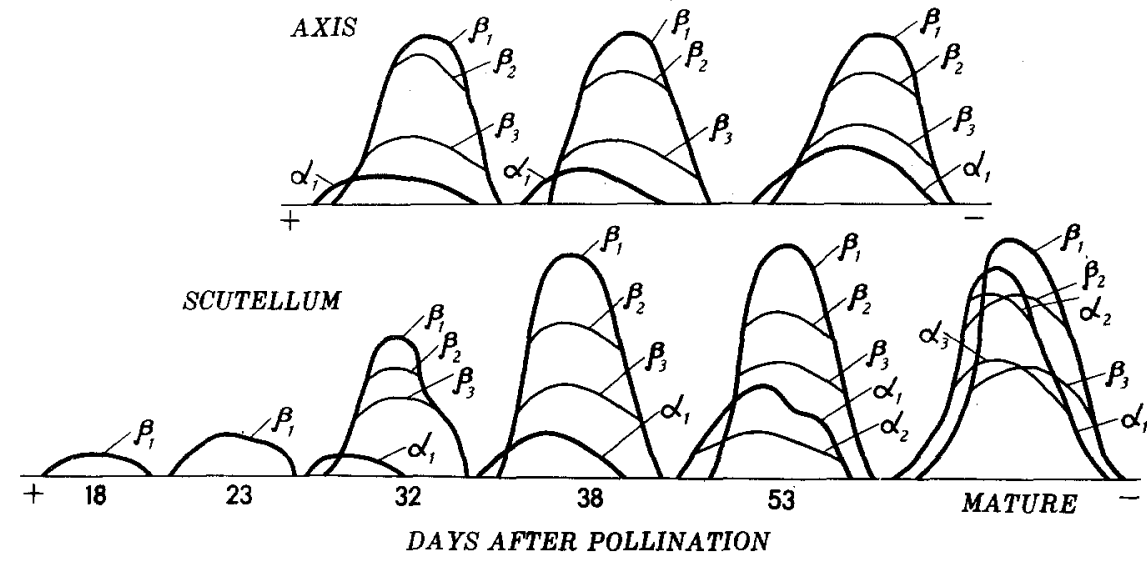

Fig. 6. Line drawing of the developing EA pattern (other antigens are omitted). On the 18 th and 23rd DAP, the whole embryos were taken for analysis; later, they were divided into scutella and embryonic axes 
means scutellum-specific proteins. In fact, when the double-diffusion test was applied to the investigation of root, coleoptile and endosperm tissues of mature, non-germinated caryopses, three to four EA appeared to be confluent with the corresponding scutellar EA (see Fig. 1D).

Thus we were able to demonstrate the sequential appearance of the EA and a specific differential pattern of EA synthesis in the developing scutellum and the embryonic axis. In the course of caryopsis maturation EA concentration in the scutellum constantly increased (see Fig. 3).

The EA rapidly disappeared from the embryo root at the very beginning of germination, and therefore we presumed these proteins to be of transient nature. Indeed, it was shown by experiments described elsewhere (Misharin et al., 1975) that most of the EA including the $\alpha$-and $\beta$-EA are degraded in the embryo before any considerable mobilization of bulk protein reserves occurred in the endosperm. Only two EA are maintained in the scutella of 4-12-day-old seedlings, and these antigens - contrary to the predominant $\alpha$ - and $\beta$-EA-are likely to be organ-specific constitutive proteins. Preliminary data obtained in our experiments with scutella isolated from non-germinated caryopses and cultured in vitro seem to support this suggestion: at least one EA was present in 28-day-old callus tissue (Fig. 7). This EA was maintained through 6 successive subcultures of callus tissue.

\section{Discussion}

The appearance of several new proteins at the onset of embryonal differentiation and the sequential accumulation of these EA in the developing maize caryopsis fit perfectly into the concept of differential gene expression in embryogenesis. Yet two other aspects of the EA behaviour in maize caryopses deserve a more detailed discussion.

The first is the possible role of the EA in the cells of the embryo. The transient nature and the high content of the predominant EA indicate that these proteins are some form of protein reserves in the embryo tissues. Little is known about the chemical properties of the EA. Our preliminary data, based upon the solubility and the dialysis behaviour of the EA, indicate that they are globulins. When globulins from the scutellum were separated by isoelectric precipitation into crude $7 S$ and $11 S$ fractions both preparations behaved as the EA in the double diffusion test (unpublished data). It is in fact most likely that we are dealing with the characteristic group of labile cereal globulins very similar to the well-known reserve globulins of legumes (for review see Derbyshire et al., 1976). A recent report by Horikoshi and Morita (1975) provides additional support for this suggestion. At least two immunochemically distinct components of $7 S$ globulin characteristic of rice embryo accumulated in the developing caryopsis and disappeared during germination in a mode closely similar to that found in maize (Misharin et al., 1975, and this paper).

The second interesting aspect of our results is the asynchronous mode of the EA accumulation in the developing scutellum. The $\beta_{1}$-EA is formed mostly during the grand period of embryo growth while the greater part of the $\alpha_{1}$-EA is accumulated later in the enlarging scutellum cells which have ceased to divide (see Fig. 3). Such a situation bears a strong resemblance to the pattern of $7 S$ and $11 S$ globulin deposition in growing bean cotyledons described by $\mathrm{Kloz}$ et al. (1966) and Millerd et al. (1971)

The authors thank Mrs. A.I. Antipina and Mrs. T.P. Pobezhimova for skillfull technical assistance.

\section{References}

Abelev, G.I.: Modification of the agar precipitin method for comparing two antigen-antiserum systems. Folia Biol. 6, 56-58 (1960)

Bonner, J.: The molecular biology of development. Oxford: Clarendon Press 1965

Boutenko, R.G., Volodarsky, A.D.: Analyse immunochimique de la differenciation cellulaire dans le culture de tissus de tabac. Physiol. vég. 6, 299-309 (1968)

Clarke, H.G.M., Freeman, T.: Quantitative immunoelectrophoresis of human serum proteins. Clin. Sci. 35, 403-413 (1968)

Crumpton, M.J.: Protein antigens: the molecular bases of antigenicity and immunogenicity. In: The Antigens, vol. 2, pp. 1-78. Sela, M., ed. New York-London: Academic Press 1974

Daussant, J., Neucere, N.J., Yatsu, L.Y.: Immunochemical studies on Arachis hypogaea proteins with particular reference to the reserve proteins. I. Characterization, distribution, and properties of $\alpha$-arachin and $\alpha$-conarachin. Plant Physiol. 44, 471-479 (1969)

Derbyshire, E., Wright, D.J., Boulter, D.: Legumin and vicilin, storage proteins of legume seeds. Phytochemistry 15, 3-24 (1976)

Horikoshi, M., Morita, Y.: Localization of $\gamma$-globulin in rice seed and changes in $\gamma$-globulin content during seed development and germination. Agr. Biol. Chem. 39, 2309-2314 (1975)

Ivanov, V.B., Lytinskaya, T.K.: A combined staining of proteins and carbohydrates by procion dyes. [In Russ.] Tsitologia $\mathbf{9}$, 1163-1165 (1967)

Ivanov, V.N., Misharin, S.I., Reimers, F.E., Khavkin, E.E. Changes of mitochondrial and cytoplasmic antigens in growing and mature cells of maize root. [In Russ.] Dokl. Akad. Nauk SSSR 218, 1229-1232 (1974)

Jensen, W.A.: Botanic histochemistry. Principles and practice. San Francisco-London: Freeman 1962

Kabat, E.A., Mayer, M.M.: Experimental immunochemistry. Springfield Ill.: Thomas 1964

Kawashima, N., Imai, A., Tamaki, E.: Studies on protein metabolism in higher plants. III. Changes in the soluble protein com- 
ponents with leaf growth. Plant and Cell Physiol. 8, 447-458 (1967)

Kiesselbach, T.A., Walker, E.R.: Structure of certain specialized tissues in the kernel of corn. Amer. J. Bot. 39, 561-569 (1952)

Kloz, J., Turková, V., Klozová, E.: Proteins found during maturation and germination of Phaseolus vulgaris L. Biol. Plantarum 8, 164-173 (1966)

Laurell, C.B.: Antigen-antibody crossed electrophoresis. Analyt. Biochem. 10, 358-361 (1965)

Lowry, O.H., Rosenbrough, N.J., Farr, A.L., Randall, R.J.: Protein measurement with the Folin phenol reagent. J. Biol. Chem. 193, 265-276 (1951)

Markert, C.L., Ursprung, H.: Developmental genetics. Englewood Cliffs, N.J.: Prentice-Hall 1971

Millerd, A., Simon, M., Stern, H.: Legumin synthesis in developing cotyledons of Vicia faba L. Plant Physiol. 48, 419-425 (1971)

Misharin, S.I., Antipina, A.I., Reimers, F.E., Khavkin, E.E.: Phase-, tissue- and organ-specific proteins of maize seedlings. [In Russ.] Dokl. Akad. Nauk SSSR 219, 473-476 (1974)

Misharin, S.I., Antipina, A.I., Ivanov, V.N., Danovich, K.N., Rej- mers, F.E., Khavkin, E.E. : Transient antigens in the developing and germinating maize seeds. [In Russ.] Dokl. Akad. Nauk SSSR 223, 479-482 (1975)

Modilevsky, Ya.S. (ed.): Cytoembryology of the major cereals. [In Russ.] Kiev: Ukrain. Akad. Sci. 1958

Osborne, T.B.: The vegetable proteins, 2nd edn. New York: Longmans-Green 1924

Pavlov, A.N., Konarev, V.G., Kolesnik, T.I., Shaiakhmetov, I.F.: Gliadins of wheat caryopsis in the course of its development. [In Russ.] Fisiol. Rastenii 22, 80--83 (1975)

Randolph, L.F.: Developmental morphology of the caryopsis in maize. J. agr. Res. 53, 881-916 (1936)

Vyasov, O.E. (ed.): Fundamentals of immunoembryology. [In Russ.] Moscow: Meditsina 1973

Wright, S.T.C.: Cellular differentiation at the molecular level with the special reference to proteins. Symp. Soc. Exp. Biol. 17, $18-39$ (1963)

Received 18 October 1976; accepted 29 March 1977 